\title{
The Implementation of Scientific Approach in the Subject of Natural Culture at SD Negeri 03 Alai Padang
}

\author{
Mafardi \\ Universitas Muhammadiyah Sumatera \\ Padang, Indonesia \\ mafardiahmad@yahoo.co.id
}

\begin{abstract}
The subject of Minangkabau Nature Culture (BAM) is one of the elective subjects in the context of the local level curriculum at the State Elementary School in Padang City. One of the proper learning approaches for implementing BAM subjects is the Scientific Approach. The Scientific Approach is applied in grade IV and V SD Negeri 03 Alai Kota Padang on the topic "Sepak Rago" and "Matrilineal Kinship System". By applying the stages: (1) the emergence, (2) asking, (3) trying, (4) reasoning, and (5) communicating, proved the students learning outcomes on these two topics are at a satisfactory level. In addition, students are motivated to participate actively in the learning process.
\end{abstract}

Keywords-Minangkabau nature culture; implementation; scientific approach; and learning outcomes

\section{INTRODUCTION}

The works undertaken to improve human resources is through the curriculum of 2013 emphasizes on improving and balancing soft skills and hard skills that cover the aspects of attitude competence, knowledge, and skill. The renewal of a learning process of 2013 curriculum laid at learning that emphasis on modern dimension of pedagogic, namely the use of scientific approach. The scientific approach steps in learning process include digging information by observing, asking, experimenting, then data or information processing, data or information presenting, followed by analyzing, thinking, then concluding and creating.

According to Mansur [1], educating children well can be done if only educator understands the society of the children along with their natural environment. Hence, human as social creature have rules as social control, that is an effort or action of a person or a party to regulate the behavior of another person. In this case, culture can be viewed as ways to overcome the problems faced by members of the cultural society. So, culture society of the students should be designed and implemented.

Urgency of the design and implemention of local culture is not only becoming a problem in the country or multicultural district in Indonesia. In Ontario, Canada, the government also pay attention to the education culture of the native tribe in Ontaria, that is the Aborijinal [2]. The Aborijinal in Ontario tend to uproot from the root culture as a result of the development of science and technology, modernization areas, and the social dynamics. Addressing this matter, the regional office of province of West Sumatera drawn the decision Number: 012.08.c.1994 about Natural Culture of Minangkabau Subject and strengthened with local regulation of the province of West Sumatra No 9 years 2009[3].Multicultural education helps students to developed their culture in the learning process. The students directly act as subjects so that interaction between groups is a matter of culture and language. tis is because students have different cultural backgrounds this sa method of learning that really teaches the multicultural fundamental[4]

Proud when using Minangkabau culture, the pride which is accompanied by the needs to encourage the sustainability of natural culture of Minangkabau through education. Therefore, Natural Culture of Minangkabau Subject is considered to develop urgently. In addition, it is also to meet the message of the constitutions[5].The major goal af cultral education aims are anti rascist and gender equality. They are to generalize differencea in students who have defferent ethnicity race and social class[6].

The complaints of the teachers of Natural Culture of Minangkabau Subject during this time because of the material that is too abstract and not associated with the actual condition in the field or the society, therefore planting the cultural values through Natural Culture of Minangkabau Subjectnot accumulates well. This research is an advanced research that has been researchers done as the implementation of the local subject curriculum of natural culture of Minangkabau subject. The study was done at SD Negeri 03 Padang which is also a national level school. The learning materials which are implemented are games of anak nagari and matrilineal kinship system.

Each learning which is done in schools surely refers to curriculum. Zais [7] said that the curriculum must be placed as the content, learning experience that is planned, experience 
under school aid, structured can produce expected learning outcomes, a written plan to do activities.

Mulyasa [8]suggested that the advantages of the 2013 are: 1) students are required to be active, creative and innovative in solving any problems they faced at school. 2) There are evaluation of all aspects. The determination of students' values are not only obtained from students' scores but also obtained from the modesty, religious, practice, attitudes and so on. 3) The character and manner education which has been integrated into all courses. 4) The competence which is in accordance with the demand function and national education targets. 5) The competence described in a holistic attitude domain, skills, and knowledge.

The 2013 curriculum known as scientific learning which learn and explain the natural phenomena with empirical aspects. Science learning emphasizes on the immediate experience to understand a matter of about nature scientifically[9]. Science is able to regarded as a means of attitudes development and certain values such as religious value, objectivity, regularity attitude, openness, practical and economic value, as well as ethics and aesthetics.

Scientific approach is intended to provide understanding to learners that information can be obtained from anywhere and anytime, not only from teachers. Teachers are the facilitators while student was the subject of learning which needs to be actively involved in the process of learning. Characteristics are actively involved to performs activities and they are trained learning by doing, so that they can make decisions independently and teachers use the model of learning that varies.

The process of scientific learning according to Kemendikbud no. 65 years 2013[10] about standard process touchs three domains, those are attitude, knowledge and skills. In relation to the concept of teaching and learning, Ormrod [10], [11] stated that the concept cannot be separated from philosophy and pracmatical sychology. In accordance with the reality, schools and teachers equally assist students to develop rich and meaningful understanding about teaching material, think critically, build and solve problems, synthesize information, do the discovery, create, manifest themselves professionally, and when they graduated, they have readiness to be capable of being a citizen who responsible and keep learningin lifetime.

\section{RESEARCH METHOD}

This research is an $\mathrm{R} \& \mathrm{D}$ which use combinination method that is combining qualitative and quantitative [12]. Qualitative data were obtained through interview. Quantitative data were obtained through experiment then the data were processed statistically.

Undertanding Matrilineal Kinship System and Marriage System Materials
TABLE I. THE QUALIFICATION OF STUDENTS' UNDERSTANDING TOWARDS THE MATRILINEAL KINSHIP SYSTEM AND MARRIAGE SYSTEM MATERIALS GRADE IV

\begin{tabular}{|c|c|l|c|c|} 
No & $\begin{array}{c}\text { The } \\
\text { Mastery }\end{array}$ & Qualifications & Frequency & Percentage \\
\hline 1 & $96-100 \%$ & Perfect & 1 & 3,70 \\
\hline 2 & $86-95 \%$ & Very good & 12 & 44,45 \\
3 & $76-85 \%$ & Good & 5 & 18,52 \\
\hline 4 & $66-75 \%$ & More than enough & 7 & 25,93 \\
\hline 5 & $56-65 \%$ & Fair & 1 & 3,70 \\
6 & $46-55 \%$ & Almost enough & 1 & 3,70 \\
\hline 7 & $36-45 \%$ & Less & 0 & 0 \\
8 & $26-35 \%$ & Less once & 0 & 0 \\
\hline 9 & $16-25 \%$ & Bad & 0 & 0 \\
\hline 10 & $0-15 \%$ & Terrible & 0 & 0 \\
& Total & & 27 & 100 \\
\hline
\end{tabular}

The number of the total score obtained by students for material kinship systems and a system of marriage grade IV SD Negeri 03 Alai Padang is 2250 with the average 2250/27= 83,33 , it is at food qualification.

Understanding Anak Nagari's game

TABLE II. THE QUALIFICATION OF STUDENTS UNDERSTANDING TOWARDS GAMES OF ANAK NAGARI GRADE V

\begin{tabular}{|c|c|l|c|c|}
\hline No & $\begin{array}{c}\text { The } \\
\text { Mastery }\end{array}$ & Qualification & Frequency & Percentage \\
\hline 1 & $96-100 \%$ & Perfect & 1 & 3,70 \\
2 & $86-95 \%$ & Very good & 5 & 18,52 \\
\hline 3 & $76-85 \%$ & Good & 13 & 48,15 \\
4 & $66-75 \%$ & More than enough & 6 & 22,23 \\
\hline 5 & $56-65 \%$ & Fair & 1 & 3,70 \\
\hline 6 & $46-55 \%$ & Almost enough & 1 & 3,70 \\
\hline 7 & $36-45 \%$ & Less & 0 & 0 \\
\hline 8 & $26-35 \%$ & Less once & 0 & 0 \\
9 & $16-25 \%$ & Bad & 0 & 0 \\
\hline 10 & $0-15 \%$ & Terrible & 27 & 0 \\
& Total & & & 100 \\
\hline
\end{tabular}

The number of the total scores obtained by the students for Anak Nagari's games grade V SD Negeri 03 Alai Padang on trial is 2210 with average $2210 / 27=81,85$, is at good qualifications.

Scientific analysis Scientific analysis which was done at grade IV and V SD Negeri 03 Padang City is as follows:

\section{Observing}

In observing, the students were given real objects by the teacher that exists in their environment. In the observation, the researcher found several things that was done by the students, those are: 1) the interaction among students about the observing object, 2) the knowledge exchanged among students in the group, 3) in observing, each students expressed opinion, ideas and responses to object that was faced, so that appeared various alternative opinion, 4) the direct contact with the senses such as eyes, so the students can see their own culture, 5) in observing, students started to open up sensitivity to the cultural environment therefore they can solve problems they found, 6) in observing, each groups concentrated and seriously observed the material object presented. 


\section{Questioning}

After the students observed carefully came up a question. When the researcher noted at the field there were several things that were done by the students, those are: 1) after observing, the students' encouragement to learn actively emergence, along with developing a question by themselves, 2) after observing, the students inspired and had desire to create a question, 3) after observing, there was thinking pattern shaped by the students to create a question.

\section{Trying}

The researchers noted that in modeling anak nagari's game, students in groups had to play the 'sepak rago'. Certain Students could do these activities well since they realize that the game that they played was come from their own culture.

\section{Assosiating}

Researcher noted that in associating activity, the students were demanded to fasten upon and analyzed information which was obtained to be analyzed as a datum then the datum was drawn into a conclusion. The activity that was done by the students at that time was group discussion, they reasoning the exact and relevant answer that they faced. In the field, the researcher saw the creative ideas that emergence which were raised by the students.

\section{Communicating}

According to the researcher notes in communicating the results, the students were given the opportunity by the teacher to give their opinions about the answers of the problems faced by the students. Beside of that, the students also conveyed their report in written and oral from in front of the class. The researchers also saw the interaction among the students and also the other groups. The communicating process happened and could train the students' braveness in argumenting, answering the questions among the friends, testing the mental that are high creativity aspect of the students.

\section{CONCLUSIONS AND SUGGESTIONS}

\section{Conclusions}

The implementation of scientific approach on Natural Culture of Minangkabau Subject at SD Negeri 03 Alai Padang City could be implemented well. Since the learning materials were in accordance with the environment culture of the students. In addition, one of the obligatory subject of the local content from primary school to high school is Natural Culture of Minangkabau Subject based on the province regulation of West Sumatera No. 9 years 2009[3]. The difficulties that were felt in teaching Natural Culture of Minangkabau Subject could be anticipated since the learning materials were based on the students' environment.

\section{Suggestions}

First, for the education authorities of Padang cities, this research could be an input and consideration for planning, development, and implementation subject in local content curriculum at the primary school level.Second, the teachers can be benefited as consideration matter and reference for planning, implementation, and evaluation of the Natural Culture of Minangkabau Subject. Third, for the other researchers that will research things that are relevant with this research, this research can be the input and development of their research about the Natural Culture of Minangkabau Subject.

\section{References}

[1]
N. Mansur, "Signifikansi Kurikulum Muatan Lokal dalam Sistem Pendidikan Sekolah," J. Ilm. Didakt. Makasar., 2011.

E. J. Faries, "Research Paper on Aboriginal Curriculum in Ontario." Pemda Provinsi Sumatera Barat., "PERDA Nomor 9 tahun 2000 tentang Ketentuan Pokok Pemerintahan Nagari. Padang:," 2000.

Cristine sleeter, "An analisys of multicultural education in United States," Harvard Educ. Publ. Gr., vol. 57, no. desember, 1987.

Kantor Wilayah Dinas Pendidikan Propinsi Sumatera Barat, "Kurikulum BAM.," 1988.

6] J. A. Banks, "The major goal af cultral education aims are anti rascist and gender equality. They are to generalize differencea in students who have defferent ethnicity race and social class.," Univ. Washingt., vol. 19, no. 1, 1993.

R. S. Zais, Curriculum: Principles and Foundation. New York: Thomas Y. Crowell, Harper \& Row Publishers, 1976.

H. . M. (2013). P. dan I. K. 2013. B. P. R. Rosdakarya., Pengembangan dan Implementasi Kurikulum. bandung: PT ROSADA KARYA, 2013.

DEPDIKNAS, Kurikulum 2013. Jakarta: Depdiknas. Jakarta: DEPDIKNAS, 2013.

KEMENDIKBUD, "Peraturan Menteri Pendidikan Dan Kebudayaan Republik Indonesia Nomor 65 Tahun2013 Tentang Standar Proses Pendidikan Dasar Dan Menengah. Jakarta.” 2013.

J. E. 2008. Ormrod, Psikologi Pendidikan: Membantu Siswa Tumbuh dan Berkembang. (Edisi ke-6). Terjemahan Educational Psychology Developing Learners, oleh Wahyu Indianti, Dkk. Jakarta: Jakarta: Erlangga., 2008.

Sugiono, Metode Penelitian Kuantitatif, dan $R \& D$. bandung: Alfabeta., 2011. 